\title{
Thermal simulation of prisms with concrete blocks in a fire situation
}

\section{Simulação térmica de prismas com blocos de concreto em situação de incêndio}
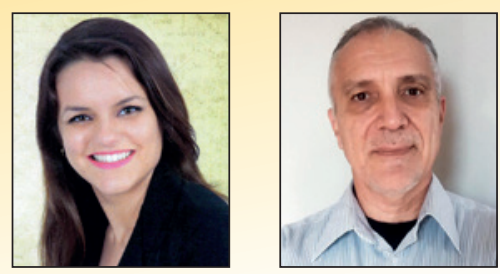

F. S. RODOVALHO

francielle rodovalho@hotmail.com https://orcid.org/0000-0003-1079-7060

M. R. S. CORRÊA a

marcio.correa@usp.br https://orcid.org/0000-0003-3224-5945

\section{Abstract}

The purpose of the current study is to verify the thermal insulation capacity of concrete block masonry in a fire situation through the thermal simulation of prisms. Initially, a prism with mortar coating on the face exposed to fire was numerically simulated and compared to experimental results provided by a company in order to validate the block thermal properties. To represent air in the block cavities, fluid-structure interaction was used in ABAQUS software. The uncoated and mortar-coated prisms on both sides were analyzed in a fire situation. The thermal insulation of the uncoated prism was maintained for more than 60 minutes and with the application of coating on both faces there was an increase of $59 \%$ of this time. The thermal fields were generated, thus leading to future thermomechanical analysis.

Keywords: concrete blocks, structural masonry, high temperatures, thermal insulation, numerical analysis.

\section{Resumo}

O presente trabalho tem como objetivo verificar a capacidade de isolamento térmico de alvenarias constituídas por blocos de concreto em situação de incêndio por meio da simulação térmica de prismas. Inicialmente, para a validação das propriedades térmicas do bloco com um experimento fornecido por uma empresa, foi simulado um prisma com revestimento em argamassa na face exposta ao incêndio. Para representar o ar presente nas cavidades dos blocos foi utilizada a interação fluido-estrutura no software ABAQUS. Verificaram-se os casos de prisma sem revestimento e com revestimento em argamassa nas duas faces, em situação de incêndio. $O$ isolamento térmico do prisma sem revestimento foi mantido por mais de 60 minutos e com a aplicação de revestimento nas duas faces do prisma ocorreu um aumento de $59 \%$ em relação a esse tempo. Os campos térmicos foram gerados possibilitando futuras análises termomecânicas.

Palavras-chave: blocos de concreto, alvenaria estrutural, elevadas temperaturas, isolamento térmico, análise numérica.

Universidade de São Paulo, Escola de Engenharia de São Carlos, Departamento de Engenharia de Estruturas, São Carlos, SP, Brasil. 


\section{Introduction}

Structural masonry is a very old constructive system that has been used on a large scale in Brazil. According to the ABCP [1], the time saved on work execution, a reduction in the volume of waste generated, technological advances and competitive pricing have made concrete block structural masonry one of the most used construction systems in the country. However, little is known about its behaviour under the effect of high temperatures.

A fire that broke out at dawn on 1st May, 2018 in a building in São Paulo, followed by its collapse, reinforces the need for studies on the behaviour of construction systems submitted to this exceptional action.

Brazil does not yet have standardised methods for designing structural masonry in fire situations. According to Leite et. al [2], there are variations in the mineralogical compositions of rocks that are used as aggregates and, therefore, each country has thickness, geometry and resistance specifications to be followed by the block industries. These factors restrict use and require a great deal of effort to adapt to international standards.

Fire resistance of a structure is related to the time when it is able to withstand the actions for which it was designed when exposed to a fire. The three main fire resistance criterion defined by Eurocode 6 Part 1-2:2005 [3] are:

- Thermal insulation (I), which is considered to be met when at any point on the surface not exposed to fire, the temperature variation does not exceed $180^{\circ} \mathrm{C}$ and the average temperature variation on the same surface does not exceed $140{ }^{\circ} \mathrm{C}$;

- Mechanical resistance $(R)$, which is satisfied when the loadbearing function is maintained in the exposure to fire for a certain period of time;

- Integrity $(E)$, when cracks or openings do not occur through which flames and gases can pass through the element.

Nahhas et al. [4] evaluated the fire resistance of a wall with dimensions of $2.80 \times 2.82(\mathrm{~m})$ and $19.7 \mathrm{~cm}$ thick comprising cellular concrete blocks experimentally and through thermal modelling. At the upper end of the wall a vertical load of $357 \mathrm{kN}$ (13 ton./m) was applied distributed by a beam, and a wall face was exposed to fire, with a temperature rise according to the ISO 834-1:1999 curve [5]. The authors assessed the temperature rise, as well as vertical and lateral displacement at different points. The test lasted about six hours, however, Nahhas et al. [4] did not specify the resistance criteria used or if wall failure occurred. In the heat transfer theoretical model, the conduction, convection, and radiation were considered. The authors concluded that this model generated reasonable results, compared to experimentally measured temperature rises. Ayala [6] experimentally evaluated the behaviour of wallettes with dimensions of $67.0 \times 68.5(\mathrm{~cm})$ and $10 \mathrm{~cm}$ thick, consisting of three rows of blocks and half-blocks of lightweight concrete at high temperatures. The samples were heated to temperatures of 200,400 600,700 and $800{ }^{\circ} \mathrm{C}$, with a temperature rise rate of $10{ }^{\circ} \mathrm{C} / \mathrm{min}$, and were then subjected to compression in increments of force until rupture was achieved. The authors concluded that temperatures of $400,600,700$ and $800{ }^{\circ} \mathrm{C}$ caused a reduction of $9,19,60$ and $83 \%$, respectively, in the compressive strength of the wallettes. Some research was carried out in Brazil on masonry consisting of ceramic blocks in a fire situation. Rosemann [7] experimentally and numerically analysed the behaviour of unloaded walls in a fire situation, subject to the temperature rise proposed by the ISO 8341:1999 curve [5], regarding the thermal insulation criterion. Four situations were observed, varied with and without applying mortar coating and with and without filling the main cavities of the ceramic blocks with sand. The author concluded that the coating and filler increased the thermal insulation capacity of the masonry by $280 \%$, which was initially 106 minutes.

Rigão [8] experimentally evaluated the behaviour of structural masonry wallettes with dimensions of $89 \times 100(\mathrm{~cm})$ and $14 \mathrm{~cm}$ thick, comprising ceramic blocks, loaded and in a fire situation. Residual strengths of mortar and prisms were initially observed. The author found that after being submitted to a temperature of $900{ }^{\circ} \mathrm{C}$, the mortar did not present any resistance and the prisms had approximately $50 \%$ of their initial resistances. In the wallettes, load increases occurred due to the vertical restraint and dilation of the materials. They remained sealed after the fire, however, as the temperature rise did not follow the standard curve, it was not possible to compare the results with fire safety standards

Various tests have already been carried out concerning concrete block masonry. In the Bloco Brasil manual [9], the final results of two concrete block masonry fire resistance tests with the same nominal dimensions are presented. One is non-loaded with class $\mathrm{C}$ blocks and the other is loaded with class $\mathrm{B}$ blocks. The thermal insulation criterion failed at similar times for the two walls. According to ABNT NBR 6136:2016 [10], the average thickness of the class $C$ block walls is slightly lower than those belonging to classes A and B. According to Bloco Brasil [9], this difference in the wall thickness of the blocks did not significantly influence the thermal insulation criterion.

By using prisms, thermal fields developed in walls can be simulated, as the thermal flow occurs transversally to the elements. In addition, by carrying out thermo-mechanical simulations, the loss of material resistance can be represented due to thermal deterioration. The advantage of using prisms is their representativeness, because they consist of blocks and mortar joints, as well as small dimensions which favour the numerical simulation which, especially in the case of thermal analysis, requires considerable discretization of the model using high computational effort.

Thus, this paper aims to analyse the thermal insulation capacity of concrete block masonry using thermal simulations of prisms in ABAQUS/CAE software (version 6.14). The thermal fields developed in the prisms were simulated so as to later verify their mechanical resistance by means of thermomechanical simulations, in another study.

The thermal properties of the blocks and mortar were validated by comparing the average temperature increase on the face exposed to the environment obtained numerically, considering the result of a masonry experiment with mortar coating on the face exposed to the fire. The uncoated and mortar coated prism cases on both sides were also verified.

\section{Thermal simulation characteristics}

The fire resistance wall test provided by the company, available in 


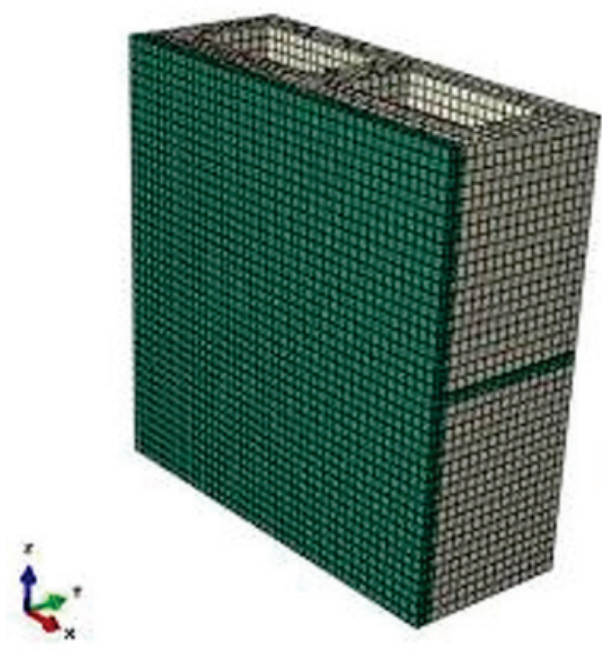

Figure 1

Mesh used on one face coated prism

Oliveira and Berto [11], was constructed with cast concrete blocks, characterized by resistance class $\mathrm{C}$ and nominal dimensions of 14 $\times 19 \times 39 \mathrm{~cm}$. The blocks were manufactured using granite stone, granite dust and CP V-ARI cement. Mortar coating was applied on only one face, which was $1.5 \mathrm{~cm}$ thick, and horizontal and vertical joints, which were $1 \mathrm{~cm}$ thick. The mortar used was industrialized, from Votomassa. The wall was in a closed environment for 30 days, protected from wind and rain.

Afterwards, with the intention of validating the thermal properties used in the block, the two- block prism with total mortar was modelled under the same conditions used in the experiment. The dimensions of the block walls were estimated so that the mean upper and lower area was the closest to the net area value of 297.95

$$
\text { Environment }\left\{\begin{array}{l}
\text { Radiation - Emissivity } 0.7 \\
\text { Convection - Coefficient } 4 \mathrm{~W} /\left(\mathrm{m}^{2} . \mathrm{K}\right)
\end{array}\right.
$$

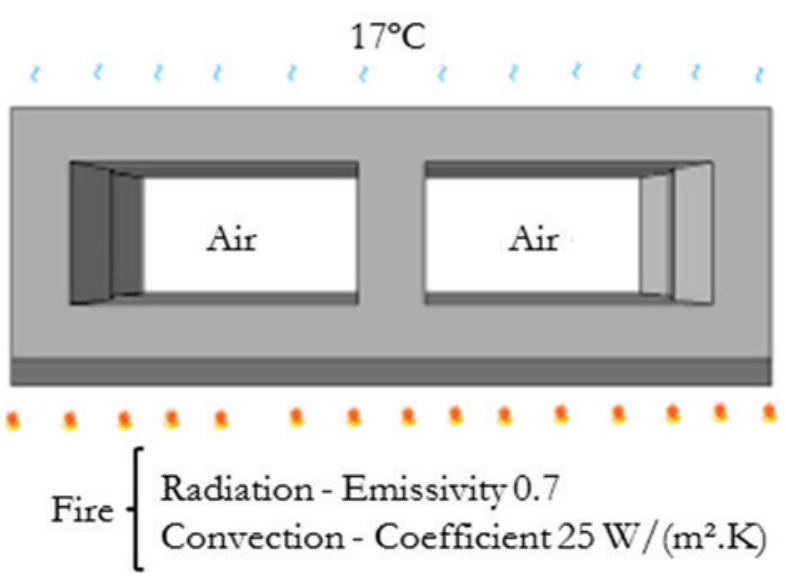

\section{Figure 2}

Schematic of the thermal modelling on one face of the coated prism $\mathrm{cm}^{2}$ measured by Oliveira [12]. In each concrete block, 6080 solid elements were used in the 320 mortar joint and in the 3042 coating, all belonging to the DC3D8 "heat transfer" family and sides with dimensions of approximately $1 \mathrm{~cm}$. The mesh used in the simulation is shown in Figure 1.

During the test, the ambient temperature was $17^{\circ} \mathrm{C}$. This temperature was applied to the prism following an initial step. Heat transfer mechanisms were considered between the flames and the prism, and from the prism to the environment, convection and radiation. On the face exposed to the fire, the kiln temperature rise was applied, presented in the experiment report, which was very close to the ISO 834-1:1999 curve [5].

The convection coefficients used in the modelling were those indicated in Eurocode 1 Part 1-2:2002 [13] for the face exposed to the environment and for face exposed to the standard fire curve. The emissivity used on both sides was the one indicated for concrete in Eurocode 2 Part 1-2:2004 [14]. We decided to use the same emissivity value for exposed and non-exposed faces, as Rosemann [7] and Nguyen et. al [15] did in their simulations. To represent air in the block cavities, the fluid-structure interaction was used, in which heat transfer occurs through conduction and convection. Figure 2 shows the thermal simulation schemematic.

The moisture content of the material influences the specific heat values. According to Oliveira and Berto [11], the moisture content of the wall was verified by means of a representative prism obtaining the result of $2 \%$ by mass. Thus, an interpolation was performed with the specific heat values of Figure 3 obtaining $1664 \mathrm{~J} /(\mathrm{kg} . \mathrm{K})$ for the $2 \%$ humidity peak. For the specific mass of the concrete block, the value of $2187 \mathrm{~kg} / \mathrm{m}^{3}$ calculated with data contained in Oliveira [12] was used. According to Andrade [16], granite aggregate in concrete has a thermal conductivity of $3.10 \mathrm{~W} /(\mathrm{m} . \mathrm{K})$ for the average temperature of $40^{\circ} \mathrm{C}$. According to Chichierchio [17], the thermal conductivity of a Class A block at ambient temperature with the same nominal dimensions and specific mass of $2150 \mathrm{~kg} \mathrm{~m}^{3}$ is $1.69 \mathrm{~W} /\left(\mathrm{m}^{\circ} \mathrm{C}\right)$. Eurocode 2 Part 1-2:2004 [14] presents the upper and lower limits of variation of the thermal conductivity according to the tempera-

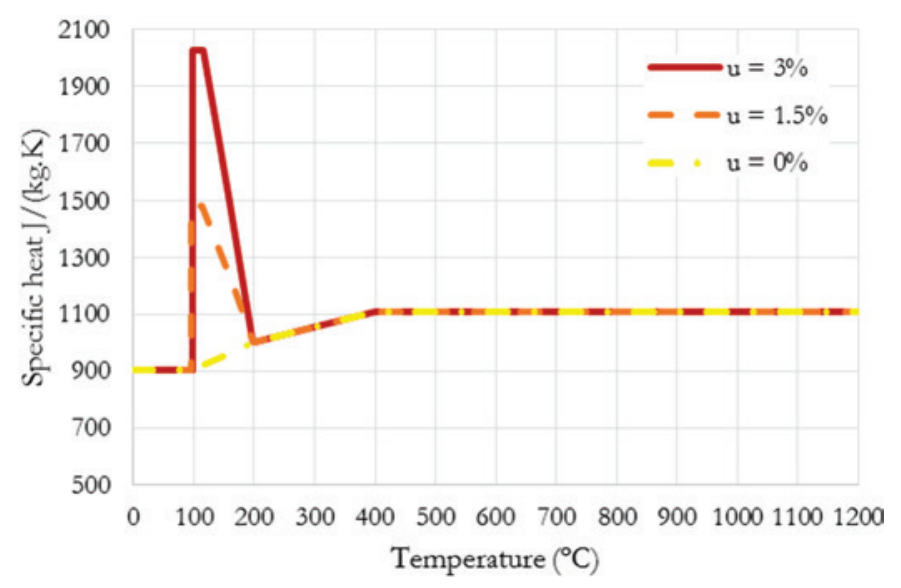

Figure 3

Specific heat variation of the concrete according to the moisture content

Source: Eurocode 2 Part 1-2:2004 [14] 


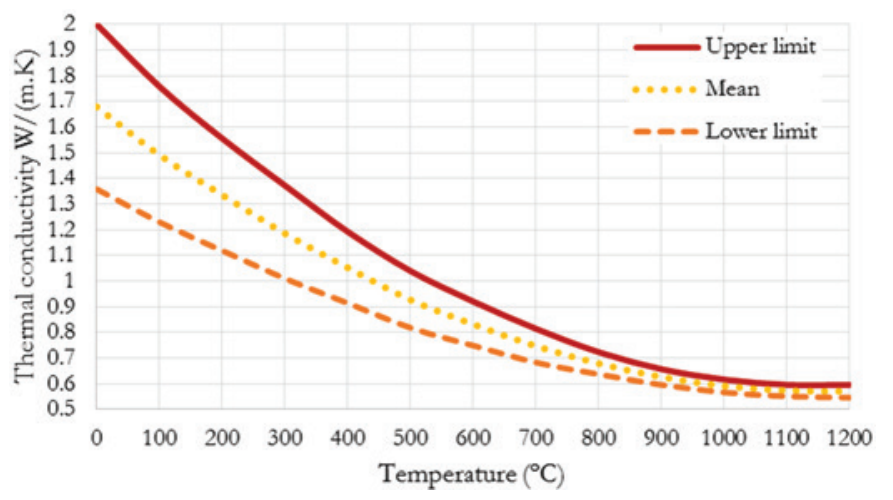

Figure 4

Thermal conductivity variation of the concrete according to the temperature rise

Source: adapted from Eurocode 2 Part 1-2:2004 [14]

ture increase for the concrete. The average of these values was calculated, obtaining the initial conductivity of $1.68 \mathrm{~W} /(\mathrm{m} . \mathrm{K})$, which was very close to the value proposed in Chichierchio [17]. Thus, we decided to use the thermal conductivity mean curve presented in Figure 4 in the thermal simulation.

The specific mass of the mortar was calculated from the mass proportion available in Oliveira [12], obtaining a value of $2180 \mathrm{~kg} / \mathrm{m}^{3}$. The thermal properties of the mortar required for the modelling, such as specific heat and thermal conductivity, were adopted as available in Rodovalho, Simões and Corrêa [18].

In the air mass, internal to the cavities, an initial temperature of $17{ }^{\circ} \mathrm{C}$ was also applied and a total of 9360 solid elements of the FC3D8 "fluid" family, with dimensions of approximately $1 \mathrm{~cm}$ were used. Figure 5 shows the mesh used in the air mass.

In Donoso [19], the thermal conductivity of air is presented varying between approximately 0.014 and $0.024 \mathrm{~W} /(\mathrm{m} . \mathrm{K})$, depending on the temperature. Concerning the fluid-structure interaction, the radiation in the cavities was not represented. To compensate for this fact, at-

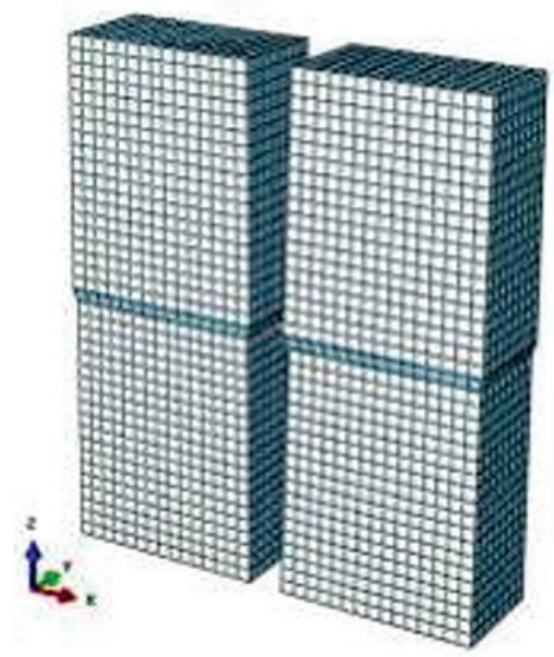

Figure 5

Mesh used in air mass
Table 1

Thermal properties of air used in the simulation

\begin{tabular}{ccc}
\hline $\begin{array}{c}\text { Temperature } \\
\mathbf{T}\left({ }^{\circ} \mathbf{C}\right)\end{array}$ & $\begin{array}{c}\text { Thermal } \\
\text { conductivity } \\
\text { W/(m.K) }\end{array}$ & $\begin{array}{c}\text { Specific heat } \\
\text { J/(kg.K) }\end{array}$ \\
\hline 17 & 0.100 & 1012 \\
60 & 0.130 & 1017 \\
80 & 0.160 & 1019 \\
100 & 0.200 & 1022 \\
200 & 0.250 & 1035 \\
300 & 0.275 & 1047 \\
400 & 0.290 & 1059 \\
500 & 0.300 & 1076 \\
1000 & 0.300 & 1139 \\
1500 & 0.300 & 1139 \\
\hline
\end{tabular}

Source: adapted from Abbott and Van Ness [20]

tempts were made to raise the thermal conductivity values of the air mass in order to obtain a suitable adjustment between the numerical and experimental temperature rises. The specific heat variation of air used in the modelling was indicated by Abbott and Van Ness [20], adopting values of $1.22 \mathrm{~kg} / \mathrm{m}^{3}$ of density and viscosity of $1.82 \mathrm{x}$ $10^{-5} \mathrm{~kg} /(\mathrm{m} . \mathrm{s})$. Table 1 shows the thermal conductivity values, already adjusted, and specific heat used for air in the present simulation.

\subsection{Uncoated mortar prism}

After considering the material properties used in the coated prism, which will be shown in item 3.1, the thermal behaviour of the uncoated prism with properties equal to the former was simulated by applying the temperature rise ISO 834-1: 1999 curve [5] for the fire and ambient temperature of $20^{\circ} \mathrm{C}$. This process was carried out during five hours of fire.

In order to reduce the processing time, the symmetry plane common to the compression and fire analyses was used because for the thermo-mechanical simulation, the thermal fields obtained from the fire simulation need to be inserted. The properties and mesh used were maintained from the previous simulation except for the coating, and by using symmetry the number of elements was halved. The symmetry plane is shown in Figure 6.

\subsection{Mortar-coated prism on both faces}

In structural masonry, it is common to have a coating on both sides

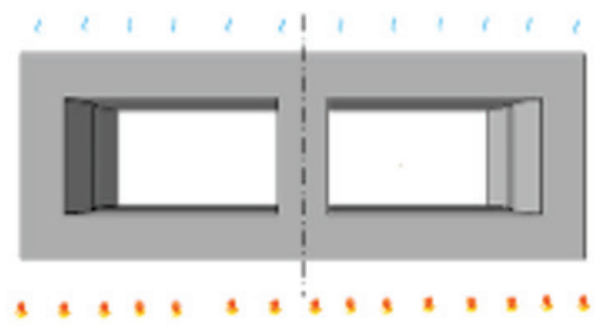

Figure 6

Symmetry plane 


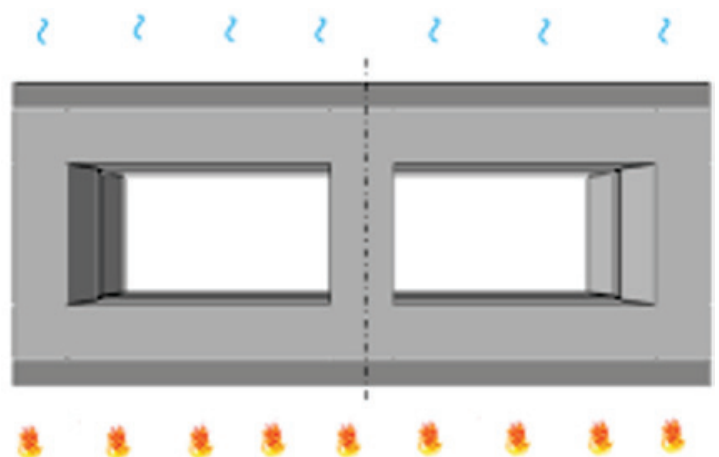

Figure 7

Schematic of the mortar-coated prism on both faces

of the wall. Thus, we chose to include this simulation. The coating was made $1.5 \mathrm{~cm}$ thick and the thermal properties of the block, mortar and air mass were maintained the same as the previous simulations. Symmetry was also considered for this case.

As was previously done, the ambient temperature of $20{ }^{\circ} \mathrm{C}$ and temperature rise according to the ISO 834-1: 1999 [5] fire curve were considered. The thermal modelling schematic of the mortarcoated prism on both faces is shown in Figure 7.

\section{Results and discussion}

\subsection{Validation of the coated prism thermal simulation on the face exposed to fire}

The thermal modelling validation was done comparing the average temperature rise on the face not exposed to the experimental fire considering the results of the average numerical temperature rise of the same face. In the fire resistance test, no temperature readings were taken in the inner wall region. Thermocouples were placed at 11 different points of the non-exposed face and the mean temperature rise was calculated considering 5 points.

During the test, the coating did not come loose. The mean temperature rise threshold of the thermal insulation criterion was reached in 104 minutes, and then had a 90-minute fire rating (CF90), as the test specimen remained sealed and stable for 120 minutes and the fire rating is defined in intervals of 30 minutes, for values between 60 and 120 minutes, according to ABNT NBR 10636:1989 [21].

The numerical mean temperature rise of the non-exposed face was calculated with measured values in the block and the mortar, projected in the centre and in the prism cavity. The mean and experimental temperature rises are shown in Figure 8.

It can be observed that initially, in the experimental temperature rise on the face not exposed to fire, there is a plateau that was not noticed in the numerical result, even with the specific heat peak for the temperature of $100^{\circ} \mathrm{C}$ according to the moisture content of $2 \%$, which should represent the latent heat of vaporization, and adjustments in the thermal conductivity of air. However, after approximately 35 minutes of fire, the results began to converge. The mean temperature variation of the thermal insulation criterion was reached by means of the numerical simulation in 106 minutes, differing in only $2 \%$ of the experimental result.

Temperature measurements were made at various points of the prism in the thermal simulation, and they were positioned in the block and the mortar joint, in the projection of the cavity and centre and at different thicknesses. The points were named after the approximate dimensions of the side of the block in centimetres, where D0 is the face closest to the fire and D14 is the face exposed to the environment. The temperature variation of these different

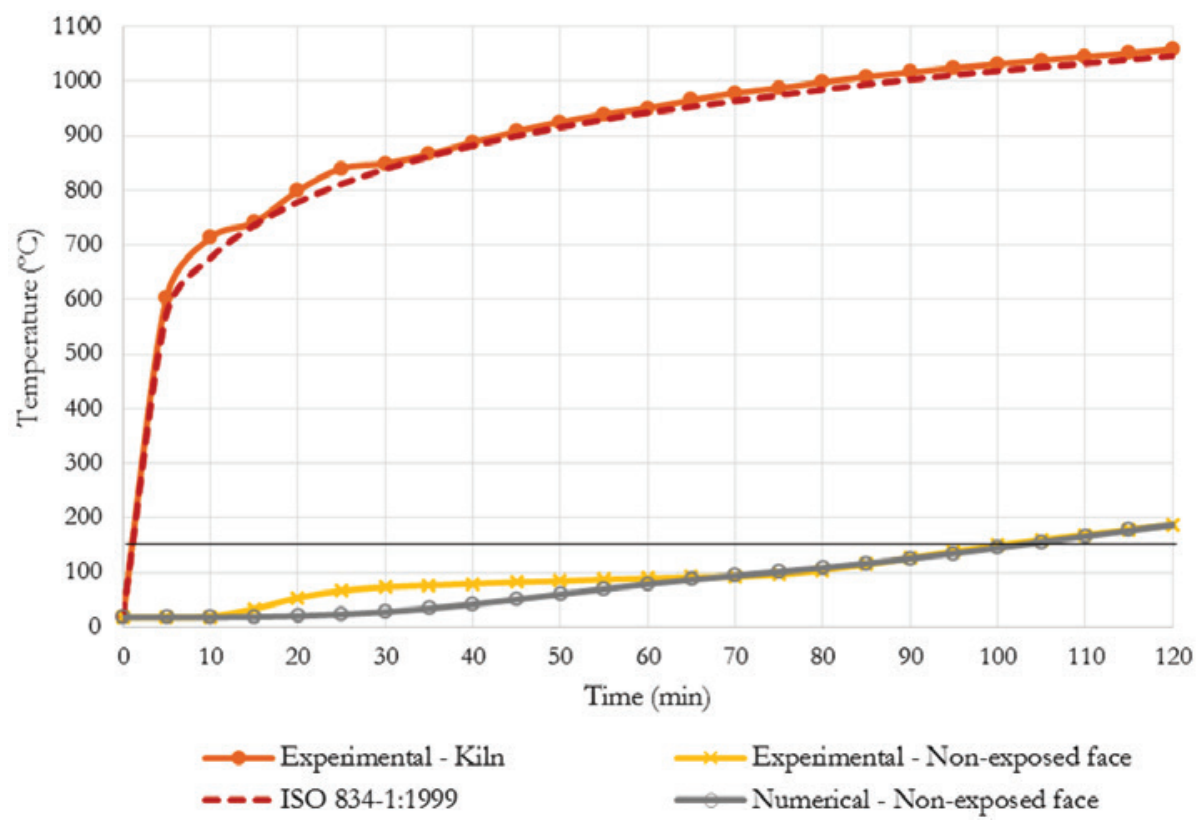

Figure 8

Numerical and experimental temperature rises 
points is presented in Figure 9. The average temperature variation for the verification of the thermal insulation criterion was calculated through the last four points.
The thermal fields developed on the coated prism on one face and in the air mass are shown in Figure 10, at 30-minute intervals.

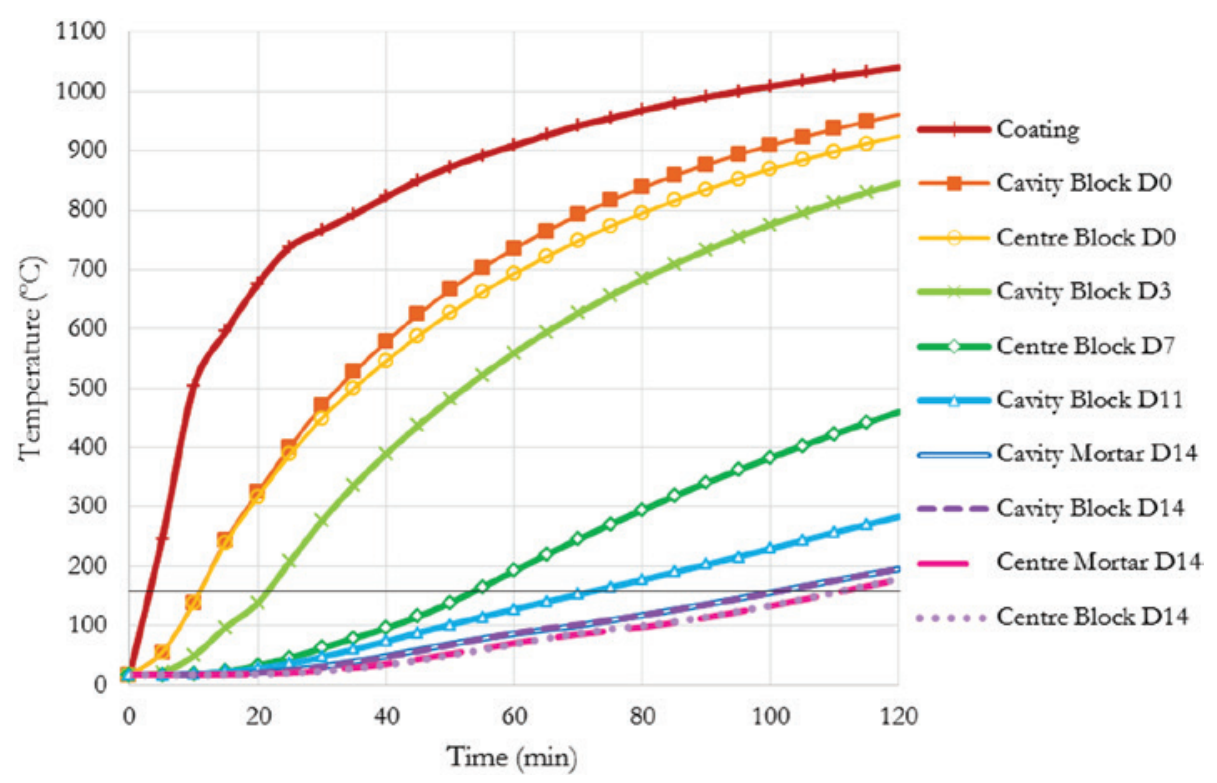

\section{Figure 9}

Temperature variation at various points of the coated prism on one face

Prism

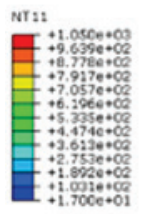

(C)

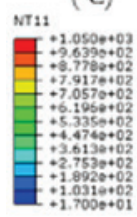

( $\mathrm{C})$
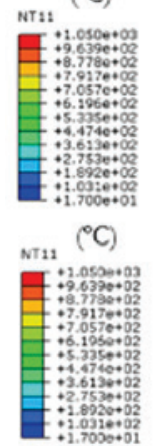

(C)
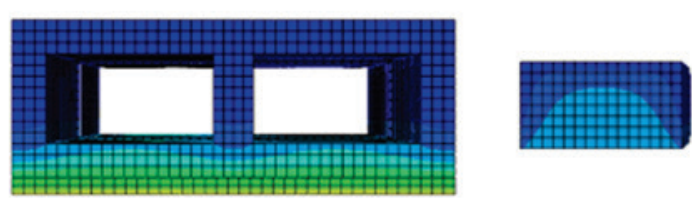

Air mass

30 minutes
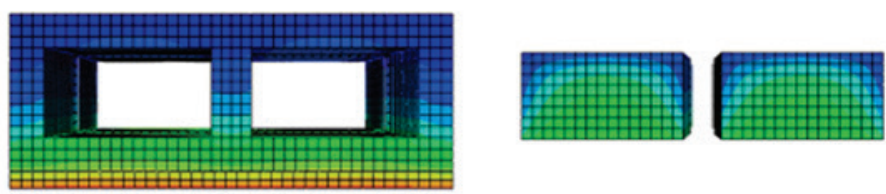

60 minutes
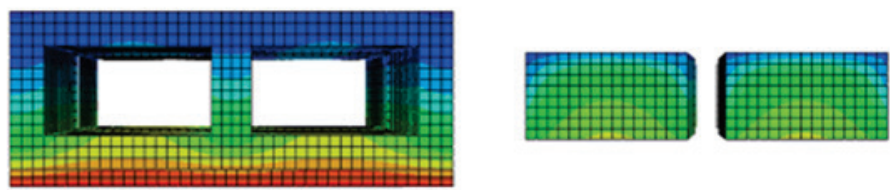

90 minutes
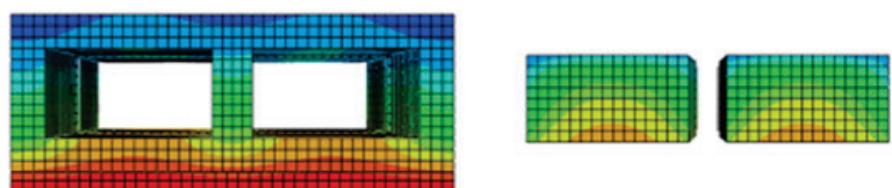

120 minutes

\section{Figure 10}

Thermal fields developed in the coated prism on one face and in air mass 


\subsection{Uncoated mortar prism}

In the present case, the mean temperature variation of the thermal insulation criterion was reached numerically at 86 minutes for the uncoated prism. According to Technical Instruction $n^{\circ}$ 08:2011 [22], an uncoated wall constructed with blocks with the same nominal dimensions has 90 minute thermal insulation, differing in only $4 \%$ of the result obtained from the thermal simulation. However, the thermal insulation capacity of 86 minutes is equivalent to the CF60 fire rating, disregarding the other criteria. According to Chichierchio [17], a wall with a supporting function, in the same conditions of the prism and constituted by blocks from the company Tecprem, has the same fire rating. Figure 11 shows the temperature rise in various points of the uncoated prism, named in the same way as the coated prism on only one face.
Figure 12 shows the thermal fields developed in the uncoated prism and the air mass.

\subsection{Mortar-coated prism on both faces}

By using mortar coating on both sides, the mean temperature rise of the thermal insulation criterion was reached in 137 minutes on the face exposed to the environment. This time is equivalent to the CF120 fire rating, disregarding the other criteria. The temperature rise in various points of the prism, named according to that done previously, are shown in Figure 13.

The thermal fields developed in the coated prism on both faces and air mass are shown in Figure 14.

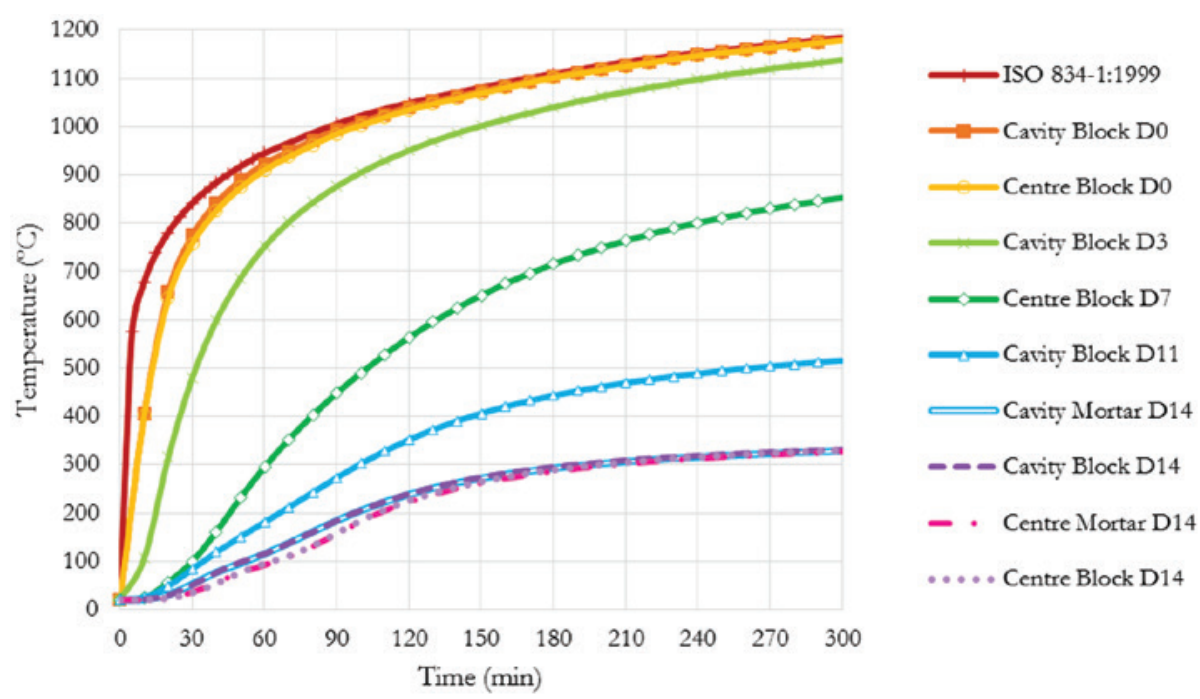

\section{Figure 11}

Temperature variation at various points of the uncoated prism
Prism
Air mass
Prism
Air mass

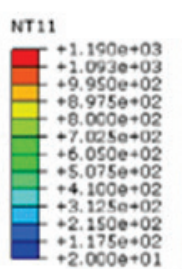

$\left({ }^{\circ} \mathrm{C}\right)$

NT

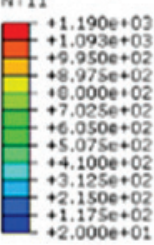

( $\left.{ }^{\circ} \mathrm{C}\right)$

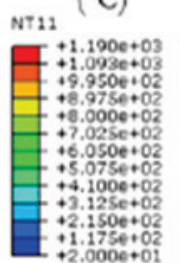

$\left({ }^{\circ} \mathrm{C}\right)$
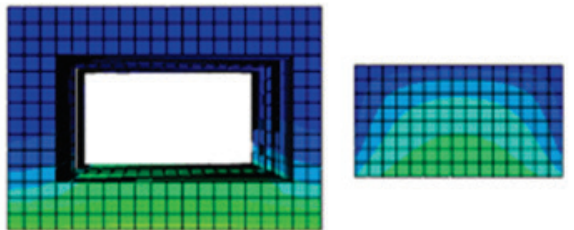

30 minutcs

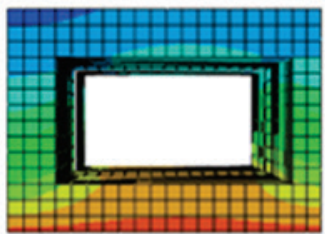

120 minutes

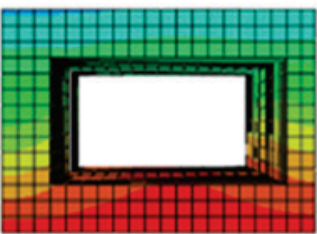

240 minutes

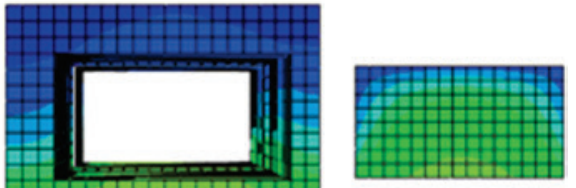

60 minutes

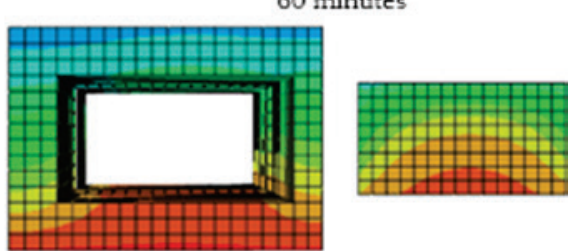

180 minutes
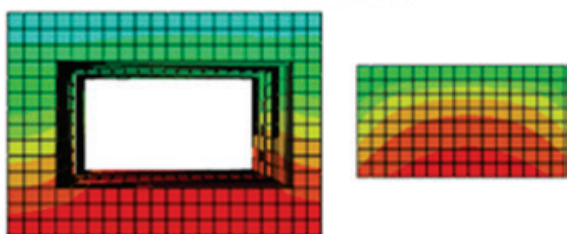

300 minutes

Figure 12

Thermal fields developed in the uncoated prism in air mass 


\section{Conclusion}

By using thermal simulations, we were able to adequately repre- sent the temperature evolution of the faces not exposed to fire, even without specific experimental data of the thermal property variations of Brazilian concrete blocks, using the properties

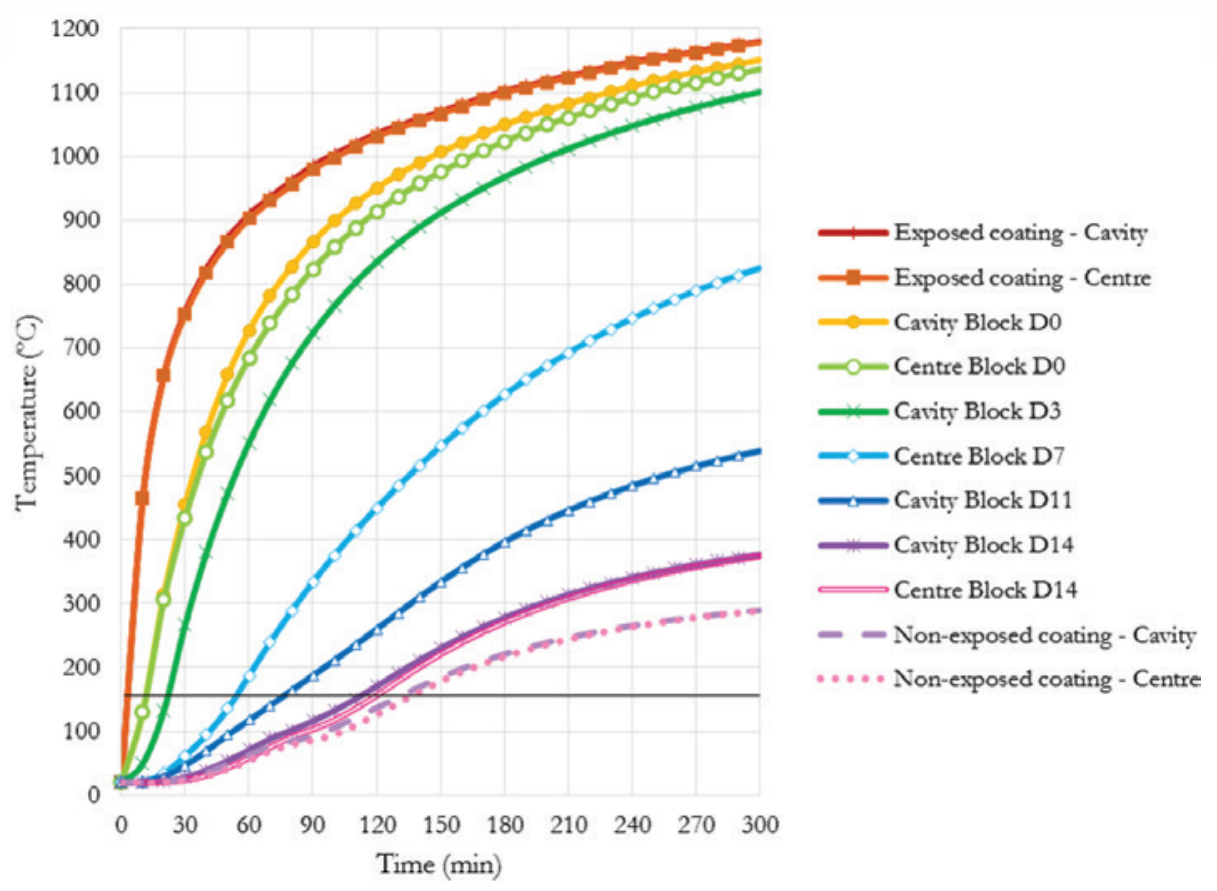

\section{Figure 13}

Temperature variation at various points of the coated prism on both faces
Prism
Air mass
Prism
Air mass
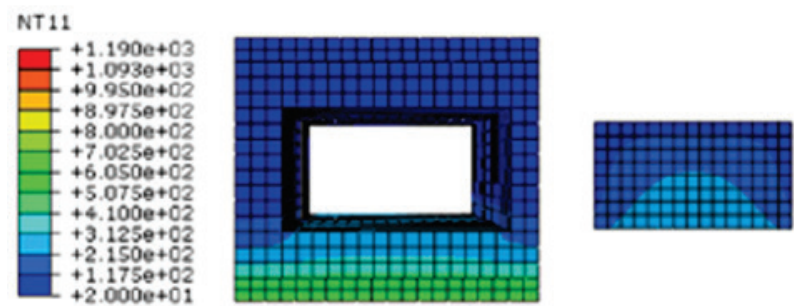

$\left({ }^{\circ} \mathrm{C}\right)$

NT 11

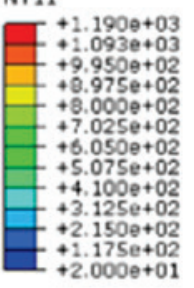

$\left({ }^{\circ} \mathrm{C}\right)$

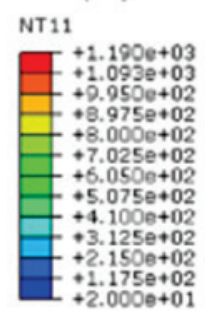

$\left({ }^{\circ} \mathrm{C}\right)$

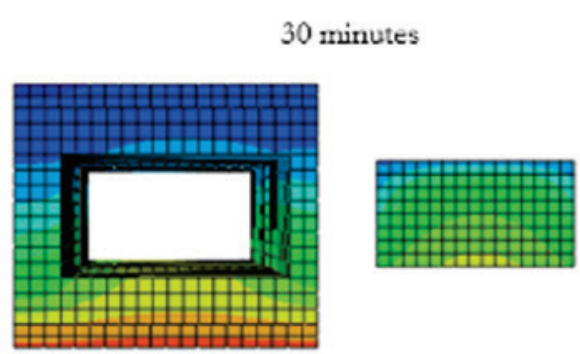

120 minutes

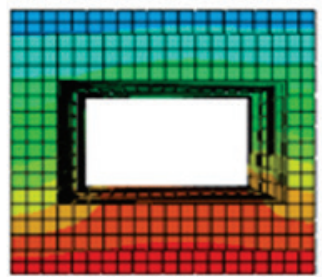

240 minutes
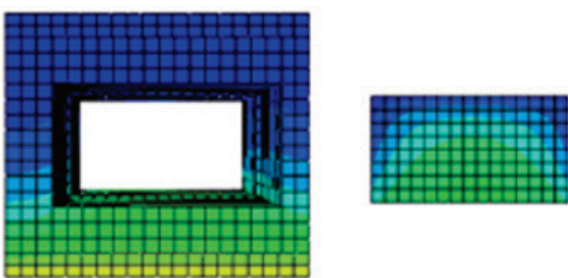

60 minutes

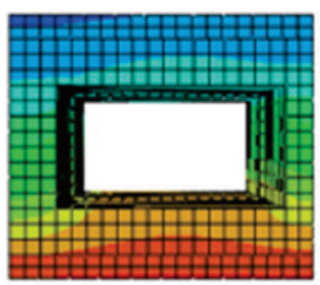

180 minutes

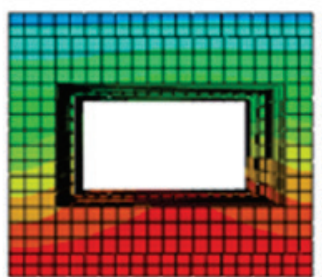

300 minutes

\section{Figure 14}

Thermal fields developed in the coated prism on both faces and in air mass 
indicated for the concrete available in Eurocode 2 Part 1-2:2004 [14].

The modeling was validated using an experiment provided by a company, with a wall made up of class $C$ blocks available in Oliveira and Berto [11] and with a fire rating result of presented in Chichierchio [17] for the masonry comprising class $\mathrm{A}$. It is expected that the thermal fields developed in blocks from both classes and with the same nominal dimensions are similar considering that the same properties and dimensions were used for both simulations. The theoretical thermal insulation of the uncoated prism was maintained for more than 60 minutes. Thus, the concrete block with the characteristics specified in the present study resisted reasonably well to this criterion.

It was observed that there was a significant beneficial effect of the thermal insulation when the mortar coating was $1.5 \mathrm{~cm}$ thick. Applying the coating only on the face exposed to the fire, as in the case of the experiment, a numerical increase of approximately $23 \%$ in the thermal insulation time was obtained in relation to the uncoated prism. In the case of coating on both sides, the predicted theoretical increase was $59 \%$.

The highest required fire resistance time required by ABNT NBR $14432: 2001$ [23] is 120 minutes. As long as the mortar coating does not come loose on the face exposed to fire, as it did not occur in the case proposed by Oliveira and Berto [11], the coated prism on both sides would theoretically meet the thermal insulation criterion. However, according to Technical Instruction $n^{\circ} 08: 2011$ [22], the highest required fire resistance time is 180 minutes for buildings that are more than $120 \mathrm{~m}$ high depending on their type of occupation. According to this reference, a wall consisting of concrete blocks with the same nominal dimensions and mortar coating on both sides, which are $1.5 \mathrm{~cm}$ thick, has thermal insulation of two hours, confirming the adequate adjustment of the simulation.

\section{Acknowledgements}

We would like to thank the National Council for Scientific and Technological Development (CNPq) for the scholarship and the company Glasser for making the results available of the masonry fire resistance test.

\section{References}

[1] ABCP - ASSOCIAÇÃO BRASILEIRA DE CIMENTO PORTLAND. Brasil é referência mundial em alvenaria estrutural. 2018. Available at: < http://www.abcp.org.br/cms/imprensa/ banco-de-pautas/brasil-e-referencia-mundial-em-alvenariaestrutural/> Accessed on: 31 May, 18.

[2] LEITE, H.A.L.; MORENO JÚNIOR, A.L; TORRES, D. L. Dimensionamento da alvenaria estrutural em situação de incêndio: Contribuição à futura normatização nacional. Ambiente Construído, Vol. 16, No. 2, pp. 89-107, Porto Alegre, 2016.

[3] EUROPEAN COMMITTEE FOR STANDARDIZATION. Eurocode 6: EN 1996-1.2: design of masonry structures: Part 1-2: general rules: structural fire design. Brussels, 2005.

[4] NAHHAS, F. AL; AMI SAADA, R.; BONNET, G.; DELMOTTE, P. Resistance to fire of walls constituted by hollow blocks: Experiments and thermal modeling. Science Direct. Applied Thermal Engineering 27, p.258-267, 2007.
[5] INTERNATIONAL ORGANIZATION FOR STANDARDIZATION. ISO 834: Fire resistance tests - elements of building construction: Part 1. General requirements. Gèneve, 1999.

[6] AYALA, F. R. R. Mechanical properties and structural behaviour of masonry at elevated temperatures. Thesis - The University of Manchester. School of Mechanical, Aerospace and Civil Engineering. 294 p. 2010.

[7] ROSEMANN, F. Resistência ao fogo de paredes de alvenaria estrutural de blocos cerâmicos pelo critério de isolamento térmico. 2011. 160 p. Dissertação (Mestrado em Engenharia Civil). Universidade Federal de Santa Catarina, Florianópolis, 2011.

[8] RIGÃO, A. O. Comportamento de Pequenas Paredes de Alvenaria Estrutural Frente a Altas Temperaturas. Dissertação (Mestrado em Engenharia Civil) - Escola de Engenharia, Universidade Federal de Santa Maria, São Maria, 2012, 142 p.

[9] BLOCO BRASIL - ASSOCIAÇÃO BRASILEIRA DA INDÚSTRIA DE BLOCOS DE CONCRETO. Manual de Desempenho - Alvenaria com Blocos de Concreto. $2^{\circ}$ Edição - Revisada e Atualizada. ISBN 978-85-87024-82-4. 2016, 38 p.

[10] ASSOCIAÇÃO BRASILEIRA DE NORMAS TÉCNICAS. NBR 6136: Blocos vazados de concreto simples para alvenaria - Requisitos. Rio de Janeiro, 2016.

[11] OLIVEIRA, C. R. M.; BERTO, A. F. Determinação da resistência ao fogo em parede sem função estrutural. São Paulo: IPT, 2015. Relatório de ensaio $n^{\circ} 1072$ 608-203. 12 p.

[12] OLIVEIRA, L. M. F. Estudo teórico e experimental do comportamento das interfaces verticais de paredes interconectadas de alvenaria estrutural. Tese (Doutorado em Engenharia de Estruturas) Escola de Engenharia de São Carlos, Universidade de São Paulo, São Carlos, 2014, 272 p.

[13] EUROPEAN COMMITTEE FOR STANDARDIZATION. Eurocode 1: EN 1991-1.2: Actions on structures: Part 1-2: General actions - Actions on structures exposed to fire. Brussels, 2002.

[14] EUROPEAN COMMITTEE FOR STANDARDIZATION. Eurocode 2: EN 1992-1.2: Design of concrete structures: Part 1-2: General rules - Structural fire design. Brussels, 2004.

[15] NGUYEN, T. D.; MEFTAH, F.; CHAMMAS, R.; MEBARKI, A. The behaviour of masonry walls subjected to fire: Modelling and parametrical studies in the case of hollow burnt-clay bricks. Fire Safety Journal 44 p. 629-641, 2009.

[16] ANDRADE, W. P. Concretos: massa, estrutural, projetado e compactado com rolo: ensaios e propriedades. Laboratório de Concreto. São Paulo: Pini, 1997.

[17] CHICHIERCHIO L. C. Conforto ambiental: desempenho térmico e acústico e proteção contra o fogo. In: Associação Brasileira da Construção Industrializada - $\mathrm{ABCl}$. Manual Técnico de Alvenaria. São Paulo, p. 119-141, 1990.

[18] RODOVALHO, F. S.; SIMÕES, Y. S.; CORRÊA, M. R. S. Análise térmica de alvenaria estrutural em situação de incêndio: um estudo do gradiente térmico. XXXVIII Iberian Latin-American Congress on Computational Methods in Engineering, Anais, Florianópolis, SC, 2017, p. 13.

[19] DONOSO, J. P. Calor, energia e transferência de calor. Universidade de São Paulo, Instituto de Física de São Carlos. 25 p. 2009. 
[20] ABBOTT, M. M.; VAN NESS, H. C. Introdução à Termodinâmica na Engenharia Química. Smith $7^{a}$ Edição, 2007.

[21] ASSOCIAÇÃO BRASILEIRA DE NORMAS TÉCNICAS. NBR 10636: Paredes divisórias sem função estrutural - Determinação da resistência ao fogo - Requisitos. Rio de Janeiro, 1989.

[22] CORPO DE BOMBEIROS DO ESTADO DE SÃO PAULO. Instrução Técnica n08/2011. Resistência ao fogo dos elementos de construção.

[23] ASSOCIAÇÃO BRASILEIRA DE NORMAS TÉCNICAS. NBR 14432: Exigências de resistência ao fogo de elementos construtivos de edificações - Procedimento. Rio de Janeiro, 2001. 